\title{
Relationship between the changes over time of bone mass and muscle health in children and adults: a systematic review and meta-analysis
}

Médéa Locquet ${ }^{1 *}$, Charlotte Beaudart ${ }^{1}$, Nancy Durieux ${ }^{2}$, Jean-Yves Reginster ${ }^{1,3}$ and Olivier Bruyère ${ }^{1,4}$

\begin{abstract}
Background: Various cross-sectional studies provide an abundance of evidence that shows a relationship between bone quantity and muscle health. However, one question remains, less-often studied: is their development - or decline - associated? The aim of the research was to conduct a systematic review and meta-analysis to summarize the studies exploring the association between changes in bone mineral density (BMD) and changes in muscle parameters (registration CRD42018093813).
\end{abstract}

Methods: We searched for prospective studies, both in children and adults, by consulting electronic databases (Ovid-MEDLINE, Ovid-AMED, Scopus). Each review steps were performed by two independent reviewers. For outcomes reported by less of 3 studies, we synthetized the results narratively. In other cases, a meta-analysis was performed, giving an overall $r$ coefficient and its 95\% confidence interval (Cl).

Results: Fifteen papers were included. In connection with the change of BMD, 10 studies concerned the parallel change of lean mass, 4 were about grip strength, and 1 was about physical performance. Children were the population of interest for 5 studies, while the aging population was the focus of the other studies. The correlation between hip BMD and lean mass was significant, with an overall coefficient $r=0.37$ (95\% Cl 0.23-0.49). High heterogeneity was observed between studies but the length of follow-up, sex and study quality did not seem to significantly influence results. The systematic review allowed some other highlights: a significant link between changes in BMD and changes in muscle strength was observed ( $p$-value $<0.05$ in the 4 studies), in addition to changes in performance (1 study, $r=0.21, p$-value $=0.004$ ).

Conclusion: Despite the heterogeneity between studies, we highlighted a significant association between the change of BMD and the change of various muscle parameters. Future studies should investigate preventive and therapeutic strategies that are based on a single entity: the 'muscle-bone unit'.

Keywords: Musculoskeletal health, Meta-analysis, Longitudinal, Muscle-bone unit, Bone mineral density

\footnotetext{
* Correspondence: medea.locquet@uliege.be

${ }^{1}$ World Health Organization Collaborating Center for Public Health Aspects of

Musculoskeletal Health and Aging, Department of Public Health,

Epidemiology and Health Economics, University of Liège, CHU B.23 - Quartier

Hôpital, Avenue Hippocrate, 13, 4000 Liège, Belgium

Full list of author information is available at the end of the article
}

(c) The Author(s). 2019 Open Access This article is distributed under the terms of the Creative Commons Attribution 4.0 International License (http://creativecommons.org/licenses/by/4.0/), which permits unrestricted use, distribution, and reproduction in any medium, provided you give appropriate credit to the original author(s) and the source, provide a link to the Creative Commons license, and indicate if changes were made. The Creative Commons Public Domain Dedication waiver (http://creativecommons.org/publicdomain/zero/1.0/) applies to the data made available in this article, unless otherwise stated. 


\section{Introduction}

A good musculoskeletal health is crucial throughout the course of life. In childhood, it allows an optimal development [1], since the acquisition of bone mass is significantly impacted by the muscle function [2]. In adulthood, good musculoskeletal health is necessary to prevent disorders affecting quality of life as osteoporosis and sarcopenia [3]. Then, in the aging process, optimal musculoskeletal health prevents the loss of functional performance and subsequently allows for better autonomy and preserve independence [4]. Indeed, direct and harmful consequences of decreased musculoskeletal health exist, including sarcopenia and osteoporosis, resulting in an increased propensity for falls and fractures, hospitalizations and, ultimately, premature death [5-10].

A body of evidence proves that the two entities of bone and muscle are highly linked due to their many interactions and interconnections. Obviously, the most noticeable link is demonstrated by the mechanical influences between these two tissues in the theory that was developed by Harold Frost [11]: There is a mechanical loading that is generated by the movement of the muscle on the bone, leading to a positive relationship between the lean masses and bone tissues. Dealing with this 'mechanostat' principle and on the "bone-muscle" unit in children and adults, different modulators can be considered, such as hormonal, nutritional, behavioral or environmental factors $[12,13]$.

From a clinical point of view, the link between lean mass and bone has already been demonstrated in many cross-sectional studies, as synthesized by a systematic review conducted in 2014 [14]. Indeed, this work concluded that lean mass was significantly associated with bone mineral density (BMD), estimating an overall correlation coefficient of 0.39 (95\% confidence interval (CI) 0.34-0.43). With regard to muscle strength, its significant cross-sectional link with BMD has already been established a few times in postmenopausal women [15-17], but the research regarding childhood or adulthood is much less plentiful. There is a similar finding regarding the link between BMD and muscle performance: some studies, especially those of participants over the age of fifty, showed a significant but moderate correlation between the quantity of bone and the physical performance of subjects [18-20].

However, fewer studies have investigated the longitudinal evolution of BMD with its parallel evolution of lean mass, muscle strength and physical performance. Therefore, we systematically recorded longitudinal studies exploring the relationship between the changes of BMD and the changes in muscle components (i.e., lean mass, muscle strength and physical performance) with the ultimate goal to synthetize the findings of each independent study using a narrative review or a meta-analysis when possible.

\section{Methods}

Each stage of our systematic review and meta-analysis rigorously respected the guidelines proposed by the Preferred Reporting Items for Systematic Reviews and Meta-Analysis (PRISMA) [21]. Our issue of interest was first correctly identified and defined using the following PICOS strategy: Population or disease - bone mass; Intervention - the effect of the passing of time (growth in the child, advanced age in the adult and the elderly); Comparator - Not applicable; Outcomes - Lean mass, muscle strength and physical performance; Study design - Prospective. Our goal was therefore to systematically search and summarize the studies describing the association between the changes in bone mass with regards to the changes in muscle function (i.e., lean mass, muscle strength and physical performance). A protocol has been developed and published on PROSPERO under the registration number CRD42018093813, where the analysis plan was specified. Subsequently, we went through the different stages detailed below: literature search, study selection, data extraction, quality evaluation, data synthesis and statistical analysis.

\section{Literature search strategy}

The Ovid-MEDLINE (1946 to August 2017), Scopus (1960 to August 2017) and Ovid-Allied and Complementary Medicine Database (AMED) (1995 to August 2017) electronic databases were searched in August 2017, with an update in December 2018, to identify the relevant studies that assessed the prospective association between changes in bone mass and in muscle components. All of the databases of interest could not be searched due to logistical limits. But additionally, a search of systematic reviews and other syntheses of previous literature was also initiated to manually identify potentially relevant scientific references in the bibliography using the Ovid-Cochrane Database of Systematic Reviews, Ovid-ACP Journal Club and Ovid-DARE databases. The main keywords that were employed comprised terms as 'Bone Mineral Density, 'Lean mass', 'Muscle Strength', 'Physical Performance', and 'Prospective Study'. No limitation for the date was applied, but a restriction was set for English or French languages. The detailed search strategy with the key words that were applied in the Ovid interface is available in Table 1.

\section{Study selection}

A first screening step, performed by two independent investigators, was based on title and abstract of each reference that was yielded by the literature search. This procedure allowed for the exclusion of irrelevant studies according to the strict eligibility criteria that are shown in Table 2. Mainly, inclusion criteria included: (1) Longitudinal cohort studies, (2) interested about changes in bone mineral density and (3) changes in muscle function 
Table 1 Search Strategy applied via Ovid

\begin{tabular}{|c|c|}
\hline 1 Bone Density/ & 29 (Musc* adj2 Disabilit*).ti,ab. \\
\hline 2 (Bone adj2 Densit*).ti,ab. & 30 Sarcopenia/ \\
\hline 3 (Bone adj2 Mineral adj2 (Densit* or & 31 Sarcopenia.ti,ab. \\
\hline Content*)).ti,ab. & 32 exp. Muscle Strength/ \\
\hline 4 Osteoporosis/ & 33 (Muscle* adj2 Strength*).ti,ab. \\
\hline 5 Osteoporos*.ti,ab. & 34 (Hand adj2 Strength*).ti,ab. \\
\hline 6 Osteoporosis, Postmenopausal/ & 35 (Grasp* adj2 Strength*).ti,ab. \\
\hline 7 Osteoporos* Postmenopausal.ti,ab. & 36 (Grip* adj2 Strength*).ti,ab. \\
\hline 8 Bone Diseases, Metabolic/ & 37 (Pinch* adj2 Strength*).ti,ab. \\
\hline 9 (Bone adj2 Metabolic adj2 Disease*).ti,ab. & 38 (Physical adj2 Performance*).ti,ab. \\
\hline 10 Osteopenia*.ti,ab. & 39 (Physical adj2 Endurance*).ti,ab. \\
\hline 11 Bone Demineralization, Pathologic/ & 40 (Endurance* adj2 Physical adj2 Activit*).ti,ab \\
\hline 12 Bone Demineralization*.ti,ab. & 41 (Physical adj2 Abilit*).ti,ab. \\
\hline 13 (Bone adj2 Loss*).ti,ab. & 42 (Physical adj2 Function*).ti,ab. \\
\hline 14 (Bone adj2 Decline*).ti,ab. & 43 or/18-42 \\
\hline 15 (Bone adj2 Weakness*).ti,ab. & 44 Cohort Studies/ \\
\hline 16 (Bone adj2 Wasting).ti,ab. & 45 Cohort Stud*.ti,ab. \\
\hline 17 or/1-16 & 46 Cohort Analys*.ti,ab. \\
\hline 18 (Musc* adj2 Tissue*).ti,ab. & 47 Follow-Up Studies/ \\
\hline 19 (Muscle adj2 Mass*).ti,ab. & 48 Follow Up Studi*.ti,ab. \\
\hline 20 (Lean adj2 Mass*).ti,ab. & 49 Longitudinal Studies/ \\
\hline 21 (Lean adj2 Body adj2 Mass*).ti,ab. & 50 Longitudinal Stud*.ti,ab. \\
\hline 22 (Lean adj2 Tissue*).ti,ab. & 51 Prospective Studies/ \\
\hline 23 (Fat Free adj2 Mass*).ti,ab. & 52 Prospective Stud*.ti,ab. \\
\hline 24 (Fat Free adj2 Body adj2 Mass*).ti,ab. & 53 Prospective Change*.ti,ab. \\
\hline 25 (Muscle* adj2 Loss*).ti,ab. & 54 or/44-53 \\
\hline 26 (Muscle* adj2 Decline*).ti,ab. & 5517 and 43 \\
\hline 27 (Muscle* adj2 Weakness*).ti,ab. & 5654 and 55 \\
\hline 28 (Muscle* adj2 Wasting).ti,ab. & 57 limit 56 to (english or french) \\
\hline
\end{tabular}

Table 2 Eligibility criteria

\begin{tabular}{|c|c|c|}
\hline & Inclusion criteria & Exclusion criteria \\
\hline Design/type of study & $\begin{array}{l}\text { Longitudinal follow-up (with at least two evaluations) } \\
\text { including retrospective cohort }\end{array}$ & $\begin{array}{l}\text { Animal studies } \\
\text { Genetic studies } \\
\text { Study protocol }\end{array}$ \\
\hline Participants & $\begin{array}{l}\text { Both men and women } \\
\text { No age restriction } \\
\text { No restriction regarding ethnicity }\end{array}$ & $\begin{array}{l}\text { Population suffering from a specific pathology } \\
\text { Population benefiting of a treatment influencing muscle/bone status } \\
\text { Population presenting a particular clinical condition } \\
\text { Population benefiting from a preventive or therapeutic intervention }\end{array}$ \\
\hline Disease & $\begin{array}{l}\text { Bone Mineral Density or Bone Mineral Content, } \\
\text { regardless of the technique employed to assess it. }\end{array}$ & \\
\hline Outcome & $\begin{array}{l}\text { A measure of muscle mass, muscle strength } \\
\text { and/or physical performance, } \\
\text { regardless of the method used } \\
\text { to assess it or the site of the } \\
\text { measurement of muscle mass and strength. }\end{array}$ & \\
\hline
\end{tabular}


(i.e., lean mass, muscle strength or physical performance). For the second stage, the two investigators independently read the full texts of the articles that were selected by the initial screening, and they scrutinized the inclusion and exclusion criteria for the identified studies. Doubts and differences of opinion about a potential inclusion were settled following a discussion between the researchers, with the intervention of a third if necessary.

\section{Data extraction}

Relevant data were independently extracted by the two reviewers according to a standardized data extraction form, which was previously pretested on a sample of two studies. Discrepancies between the two collaborators were solved by discussion, with mediation from a third peer if needed. The following data were extracted: first author; journal name; year of publication; country; study objective; sociodemographic data; sample size; time of follow-up; tools and cut-offs used to assess bone and muscle components; statistical outcomes (i.e., correlation coefficient or $\beta$ coefficient); adjustment factors (i.e., variables known to significantly impact bone and muscle health; conclusion; potential conflicts of interest and funding. Authors and coauthors were systematically contacted by email if one of these data were unavailable in their report.

\section{Quality assessment}

All included studies were appraised for their methodological quality by two independent reviewers using the Newcastle-Ottawa Scale (NOS) for cohort studies; this scale was composed of three grades: group selection, comparability, exposure and outcome assessment. A maximum of 9 points could be granted, with a score of 9 thus representing the highest methodological quality. For this evaluation, disagreements between the two reviewers were resolved thanks to the opinion and advice of a third expert. The quality assessment was used to investigate its impact on pooled results.

\section{Data synthesis and statistical analysis}

A descriptive analysis of the included studies has been performed under the format of a narrative report. Some data that were required for the meta-analysis were missing. To counter this, first and/or last authors were contacted by email for additional information. For each association of changes in BMD and changes in lean mass that was reported by at least three papers depending on the site of measurement (i.e., total hip, femoral neck, lumbar spine or total body), a meta-analysis was undertaken, combining the statistical results of each study to determine an overall effect size, which was expressed as a correlation coefficient $\mathrm{r}$ with its $95 \%$ confidence interval (CI) and $p$-value, reported visually through a forest plot. Six studies shared association results after their adjustments, meaning that these analyses computed in a multivariable model, yielding a $\beta$ coefficient with its standard error. We have contacted all of the authors of the different studies that provided only the $\beta$ coefficient to obtain the data concerning the coefficient of correlation $r$. Only one author sent us the new exact $r$ value [22]. In the other cases, we computed the correlation coefficient $r$ from the $\beta$ coefficient, following the formula proposed by Peterson and Brown, in 2009 [23]. Indeed, as suggested by these authors, this method (i.e., finding the $r$ from the $\beta$ ) generally generates an accurate estimate of the effect size, giving a definite advantage for completing the meta-analysis, considering that the sampling errors would be more numerous if we excluded studies simply because they did not report the correlation coefficient $r$ [23]. Since we assumed a priori that the correlation estimates could fluctuate across studies because of a real association in each study but also by chance (and, subsequently, sampling variability), we used random-effects models to combine the results of the studies to find a pooled effect size, using the HedgesOlkin method to calculate the overall correlation coefficient. Moreover, the statistic test $\mathrm{I}^{2}$, an estimator of inconsistency, as well as the $x^{2}$ test allowed for us to explore the heterogeneity [24]. A one-way sensitivity analysis was also performed to evaluate the consistency of our results when omitting one study at a time, and we repeated this process for each study. This one-study removed method, usual sensitivity analysis for metaanalysis, can help to identify a specific study as a source of heterogeneity. A subgroup analysis was conducted because of the assumption of differences based on the life-course position of the individuals who were evaluated (i.e., children or older adults). Difference between groups was assessed by performing a Q-test based on analysis of variance. To investigate potential other sources of heterogeneity modifying the association between the evolution of bone mass in parallel with that of lean mass, we computed meta-regression models, which are composed of different moderators: mean age, quality of study, length of follow-up and sex of participants studied. To estimate the presence of a potential publication bias, we did not visually inspect the funnel plots since less than 10 studies were included in the different meta-analyses, but we instead used the Egger's regression asymmetry test to detect it. In each statistical result, a $p$-value equal or less than the $5 \%$ critical level was considered as statistically significant. All processes that were undertaken for the meta-analysis were realized using the software package Comprehensive Meta-Analysis, version 2 (Biostat, USA). 


\section{Results}

\section{Rendering of our literature search}

The search through the literature yielded 1889 relevant references, after removing 49 duplicates. We additionally found, by handsearch, 3 relevant studies. From these 1892 articles, after a long process of review and discussion (Fig. 1), fifteen studies were finally included [22, 25-38], detailed as follows:

- 10 studies examining the link between evolution of lean mass and evolution of bone mass;

- 4 studies focusing on the link between evolution of muscle strength and evolution of bone mass;

- 1 study dealing with the link between evolution of physical performance and evolution of bone mass.

At the end of December 2018, we made an update to our search and relaunched our search strategy within the databases. No new relevant references were identified for our subject of interest.

\section{Characteristics of the included studies}

The general characteristics of the 15 references included are detailed in Table 3 . These studies were published between 1997 and 2015. The population of interest was children or young adults for 5 studies [25-27, 32, 33], and the population of interest of the other studies were in female around the menopause age or individuals from the older age (i.e., older women and/or older men). With regards to the gender of the participants, 10 studies only focused on female subjects, 2 studies on male subjects only [27, 39], and 3 other studies consisted of a population of both men and women [32, 33, 37]. The duration of follow-up of these longitudinal studies ranges from 1 year to 10 years. The instrument that was used to assess bone and lean mass was the Dual Energy X-ray Absorptiometry (DXA) device. Muscle strength was measured with a handgrip dynamometer $[28,29,38]$ or a chair dynamometer [26] and the physical performance was

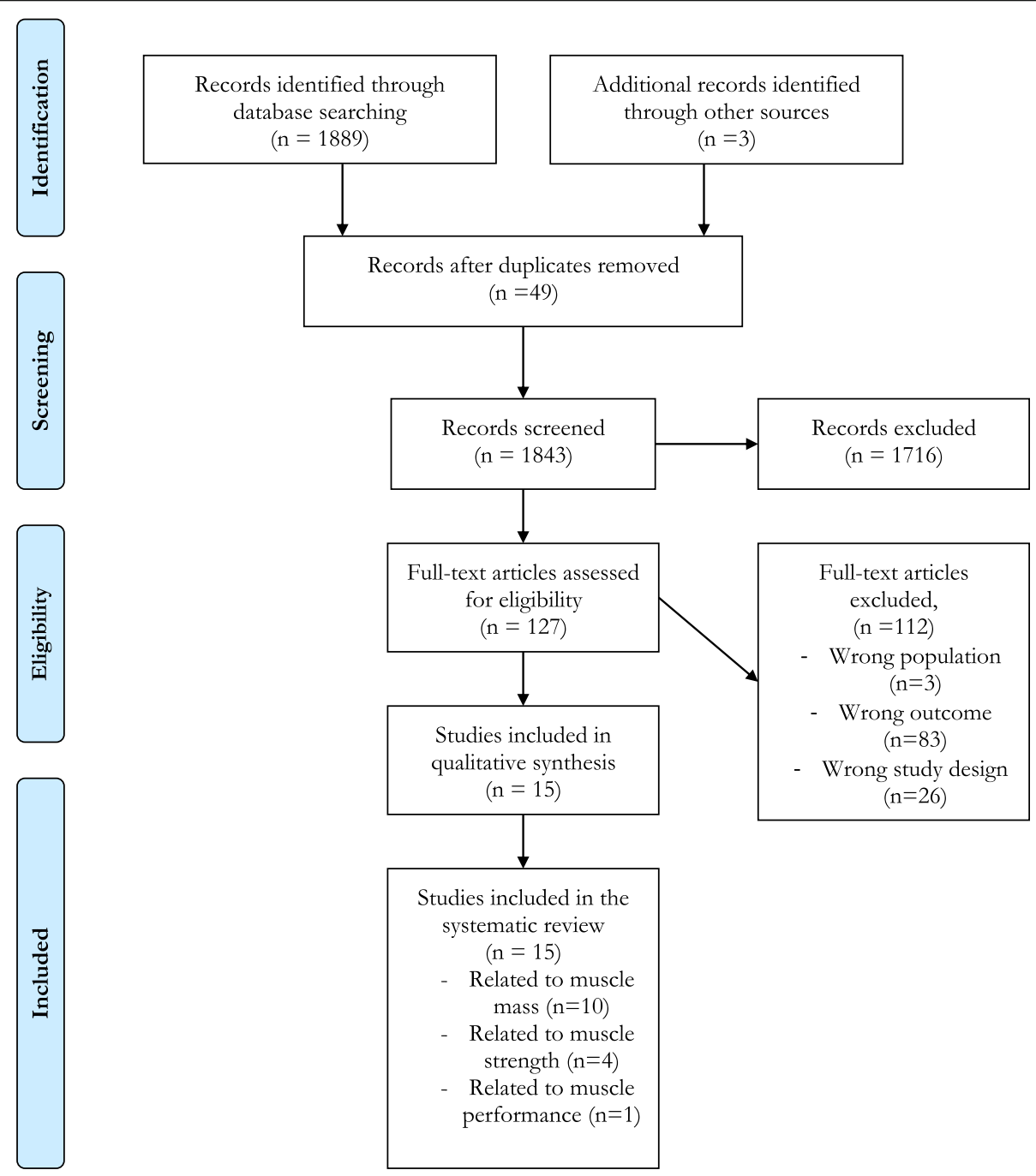

Fig. 1 Detailed literature search flow diagram 
Table 3 Characteristics of studies

\begin{tabular}{|c|c|c|c|c|c|c|}
\hline \multirow[t]{2}{*}{ First author, year } & \multirow{2}{*}{$\begin{array}{l}\text { Population } \\
\text { " } n \text { " and type of population } \\
\text { Sex ratio }\end{array}$} & \multirow{2}{*}{$\begin{array}{l}\text { Time } \\
\text { of } \\
\text { follow- } \\
\text { up }\end{array}$} & \multirow{2}{*}{$\begin{array}{l}\text { Measure of bone quantity } \\
\text { Unit } \\
\text { Site(s) } \\
\text { Tool }\end{array}$} & \multicolumn{2}{|c|}{ Measure of muscle components } & \multirow[b]{2}{*}{$\begin{array}{l}\text { Physical } \\
\text { performance } \\
\text { Unit } \\
\text { Tool }\end{array}$} \\
\hline & & & & $\begin{array}{l}\text { Muscle } \\
\text { Mass } \\
\text { Unit } \\
\text { Site } \\
\text { Tool }\end{array}$ & $\begin{array}{l}\text { Muscle strength } \\
\text { Unit } \\
\text { Site } \\
\text { Tool }\end{array}$ & \\
\hline $\begin{array}{l}\text { Arabi et al., } \\
2012 \text { [36] }\end{array}$ & $\begin{array}{l}192 \text { older subjects } \\
\text { (65-85 years) } \\
66.7 \% \text { of male }\end{array}$ & $\begin{array}{l}4.2 \\
\text { years }\end{array}$ & $\begin{array}{l}\text { Bone mineral density } \\
\text { Hip, femoral neck, } \\
\text { lumbar spine } \\
\text { DEXA }\end{array}$ & $\begin{array}{l}\text { Lean } \\
\text { mass } \\
\text { Subtotal } \\
\text { body } \\
\text { DEXA }\end{array}$ & & \\
\hline $\begin{array}{l}\text { Bleicher et al., } \\
2011 \text { [38] }\end{array}$ & $\begin{array}{l}1114 \text { older men } \\
\text { Not applicable }\end{array}$ & $\begin{array}{l}2.1 \\
\text { years }\end{array}$ & $\begin{array}{l}\text { Bone mineral density } \\
\text { Hip } \\
\text { DEXA }\end{array}$ & $\begin{array}{l}\text { Lean } \\
\text { mass } \\
\text { Total } \\
\text { body } \\
\text { DEXA }\end{array}$ & & \\
\hline $\begin{array}{l}\text { Chen et al.., } \\
1997 \text { [39] }\end{array}$ & $\begin{array}{l}45 \text { postmenopausal women } \\
\text { Not applicable }\end{array}$ & 1 year & $\begin{array}{l}\text { Bone mineral density } \\
\text { Hip, femoral neck, lumbar } \\
\text { spine, total body } \\
\text { DEXA }\end{array}$ & $\begin{array}{l}\text { Lean } \\
\text { mass } \\
\text { Total } \\
\text { body } \\
\text { DEXA }\end{array}$ & & \\
\hline $\begin{array}{l}\text { Hrafnkelsson et al., } \\
2013 \text { [31] }\end{array}$ & $\begin{array}{l}164 \text { school children } \\
\text { of } 7 \text { years } \\
57.3 \% \text { of male }\end{array}$ & 2 years & $\begin{array}{l}\text { Bone mineral density } \\
\text { Hip, femoral neck, } \\
\text { total body } \\
\text { DEXA }\end{array}$ & $\begin{array}{l}\text { Lean } \\
\text { mass } \\
\text { Total } \\
\text { body } \\
\text { DEXA }\end{array}$ & & \\
\hline $\begin{array}{l}\text { Liu-Ambrose et al., } \\
2006 \text { [22] }\end{array}$ & $\begin{array}{l}53 \text { premenopausal women } \\
\text { Not applicable }\end{array}$ & $\begin{array}{l}12 \\
\text { years }\end{array}$ & $\begin{array}{l}\text { Bone mineral density } \\
\text { Hip, lumbar spine, } \\
\text { total body } \\
\text { DEXA }\end{array}$ & $\begin{array}{l}\text { Lean } \\
\text { mass } \\
\text { Total } \\
\text { body } \\
\text { DEXA }\end{array}$ & & \\
\hline $\begin{array}{l}\text { Milliken et al., } \\
2009 \text { [29] }\end{array}$ & $\begin{array}{l}167 \text { postmenopausal women } \\
\text { (40-65 years) } \\
\text { Not applicable }\end{array}$ & 4 years & $\begin{array}{l}\text { Bone mineral density } \\
\text { Hip, femoral neck } \\
\text { DEXA }\end{array}$ & $\begin{array}{l}\text { Lean } \\
\text { mass } \\
\text { Total } \\
\text { body } \\
\text { DEXA }\end{array}$ & & \\
\hline $\begin{array}{l}\text { Cadogan et al., } \\
1998 \text { [34] }\end{array}$ & $\begin{array}{l}182 \text { elderly community- } \\
\text { dwelling women } \\
\text { Not applicable }\end{array}$ & 2 years & $\begin{array}{l}\text { Bone mineral density } \\
\text { Total body } \\
\text { DEXA }\end{array}$ & $\begin{array}{l}\text { Lean } \\
\text { mass } \\
\text { Total } \\
\text { body } \\
\text { DEXA }\end{array}$ & & \\
\hline $\begin{array}{l}\text { Vicente-Rodriguez et al., } \\
2005 \text { [27] }\end{array}$ & $\begin{array}{l}42 \text { prepubertal boys } \\
\text { Not applicable }\end{array}$ & $\begin{array}{l}3.3 \\
\text { years }\end{array}$ & $\begin{array}{l}\text { Bone mineral density } \\
\text { Hip, femoral neck } \\
\text { DEXA }\end{array}$ & $\begin{array}{l}\text { Lean } \\
\text { mass } \\
\text { Total } \\
\text { body } \\
\text { DEXA }\end{array}$ & & \\
\hline $\begin{array}{l}\text { Young et al., } \\
2001[25]\end{array}$ & $\begin{array}{l}286 \text { female twins } \\
\text { aged } 8-26 \text { years } \\
\text { Not applicable }\end{array}$ & $\begin{array}{l}1.8 \\
\text { years }\end{array}$ & $\begin{array}{l}\text { Bone mineral density } \\
\text { Hip, femoral neck, } \\
\text { lumbar spine } \\
\text { DEXA }\end{array}$ & $\begin{array}{l}\text { Lean } \\
\text { mass } \\
\text { Total } \\
\text { body } \\
\text { DEXA }\end{array}$ & & \\
\hline $\begin{array}{l}\text { Heidemann et al., } \\
2015 \text { [32] }\end{array}$ & $\begin{array}{l}683 \text { children } \\
\text { (preschool to } 4 \text { th grade) } \\
50.9 \% \text { of male }\end{array}$ & 2 years & $\begin{array}{l}\text { Bone mineral } \\
\text { content } \\
\text { Total body } \\
\text { DEXA }\end{array}$ & $\begin{array}{l}\text { Lean } \\
\text { mass } \\
\text { Subtotal } \\
\text { body } \\
\text { DEXA }\end{array}$ & & \\
\hline $\begin{array}{l}\text { Wang et al., } \\
2007[26]\end{array}$ & $\begin{array}{l}221 \text { pubertal girls } \\
\text { (10-13 years) } \\
\text { Not applicable }\end{array}$ & 2 years & $\begin{array}{l}\text { Bone mineral content } \\
\text { Total body, left arm, } \\
\text { left leg } \\
\text { DEXA }\end{array}$ & & $\begin{array}{l}\text { Maximal Isometric } \\
\text { Voluntary } \\
\text { Contraction } \\
\text { left elbow flexors, left } \\
\text { leg extensors } \\
\text { Dynamometer chair }\end{array}$ & \\
\hline
\end{tabular}


Table 3 Characteristics of studies (Continued)

\begin{tabular}{|c|c|c|c|c|c|c|}
\hline \multirow[t]{2}{*}{ First author, year } & \multirow{2}{*}{$\begin{array}{l}\text { Population } \\
\text { " } n \text { " and type of population } \\
\text { Sex ratio }\end{array}$} & \multirow{2}{*}{$\begin{array}{l}\text { Time } \\
\text { of } \\
\text { follow- } \\
\text { up }\end{array}$} & \multirow{2}{*}{$\begin{array}{l}\text { Measure of bone quantity } \\
\text { Unit } \\
\text { Site(s) } \\
\text { Tool }\end{array}$} & \multicolumn{2}{|c|}{ Measure of muscle components } & \multirow[b]{2}{*}{$\begin{array}{l}\text { Physical } \\
\text { performance } \\
\text { Unit } \\
\text { Tool }\end{array}$} \\
\hline & & & & $\begin{array}{l}\text { Muscle } \\
\text { Mass } \\
\text { Unit } \\
\text { Site } \\
\text { Tool }\end{array}$ & $\begin{array}{l}\text { Muscle strength } \\
\text { Unit } \\
\text { Site } \\
\text { Tool }\end{array}$ & \\
\hline $\begin{array}{l}\text { Sirola et al., } \\
2006 \text { [28] }\end{array}$ & $\begin{array}{l}971 \text { peri- and } \\
\text { postmenopausal women } \\
\text { Not applicable }\end{array}$ & $\begin{array}{l}5.9 \\
\text { years }\end{array}$ & $\begin{array}{l}\text { Bone mineral density } \\
\text { Lumbar spine, } \\
\text { femoral neck } \\
\text { DEXA }\end{array}$ & & $\begin{array}{l}\text { Kilopascal } \\
\text { Handgrip } \\
\text { Pneumatic } \\
\text { dynamometer }\end{array}$ & \\
\hline $\begin{array}{l}\text { Sirola et al., } \\
2006 \text { [11] }\end{array}$ & $\begin{array}{l}587 \text { peri- and } \\
\text { postmenopausal women } \\
\text { Not applicable }\end{array}$ & $\begin{array}{l}10.3 \\
\text { years }\end{array}$ & $\begin{array}{l}\text { Bone mineral density } \\
\text { Lumbar spine, } \\
\text { femoral neck } \\
\text { DEXA }\end{array}$ & & $\begin{array}{l}\text { Kilopascal } \\
\text { Handgrip } \\
\text { Pneumatic } \\
\text { dynamometer }\end{array}$ & \\
\hline $\begin{array}{l}\text { Sirola et al., } \\
2005 \text { [37] }\end{array}$ & $\begin{array}{l}622 \text { peri- and } \\
\text { postmenopausal women } \\
\text { Not applicable }\end{array}$ & $\begin{array}{l}10.3 \\
\text { years }\end{array}$ & $\begin{array}{l}\text { Bone mineral density } \\
\text { Lumbar spine, } \\
\text { femoral neck } \\
\text { DEXA }\end{array}$ & & $\begin{array}{l}\text { Kilopascal } \\
\text { Handgrip } \\
\text { Pneumatic } \\
\text { dynamometer }\end{array}$ & \\
\hline $\begin{array}{l}\text { Kwon et al., } \\
2007 \text { [30] }\end{array}$ & $\begin{array}{l}182 \text { elderly community- } \\
\text { dwelling women } \\
\text { Not applicable }\end{array}$ & 2 years & $\begin{array}{l}\text { Bone mineral density } \\
\text { Forearm } \\
\text { DEXA }\end{array}$ & & & $\begin{array}{l}\text { Walking } \\
\text { speed } \\
5-m\end{array}$ \\
\hline
\end{tabular}

established on the basis of a standard walk test of $5 \mathrm{~m}$ [31]. One study recorded conflicts of interest [22], 6 others recorded no conflict of interest, and $8 \mathrm{manu}-$ scripts did not mention the presence or absence of it. Additionally, 14 out of 15 studies are funded by a foundation, ministry, grant or national institute, and a single [40] study does not report whether or not they obtained a source of funding. The different studies are of variable quality (Table 4), from satisfactory (i.e., 5/9 points) to excellent (i.e., 9/9 points) as defined arbitrarily. Studies

Table 4 Newcastle-Ottawa Scale score for included studies

\begin{tabular}{ll}
\hline Studies & $\begin{array}{l}\text { Total score } \\
\text { (/9 points) }\end{array}$ \\
\hline Arabi et al., 2012 [36] & 7 points \\
Bleicher et al., 2011 [38] & 9 points \\
Chen et al., 1997 [39] & 8 points \\
Hrafnkelsson et al., 2013 [31] & 8 points \\
Liu-Ambrose et al., 2006 [22] & 8 points \\
Milliken et al., 2008 [29] & 8 points \\
Cadogan et al. [34], & 8 points \\
Vicente-Rodriguez et al., 2005 [27] & 7 points \\
Young et al., 2001 [25] & 5 points \\
Heidemann et al. [32], & 6 points \\
Wang et al., 2007 [26] & 7 points \\
Sirola et al., 2006 [11] & 7 points \\
Sirola et al., 2005 [28] & 7 points \\
Sirola et al., 2006 [37] & 7 points \\
Kwon et al., 2007 [30] & 9 points \\
\hline
\end{tabular}

of lesser quality usually have difficulties in representativeness of the sample.

\section{Relationship between changes in bone mass and changes in lean mass}

We have therefore identified 10 articles focusing on the parallel evolution of bone and lean mass. In regards of clinical considerations, we separated our analysis in two ways:

When the measurement of the BMD at different sites of the skeleton corresponding to the measurement of different bone compartments whose trabecular bone and cortical bone content was variable, we decided to perform a meta-analysis per measurement site of this BMD.

The bone mineral content (BMC) can significantly differ from bone mineral density, so the study of Heidemann et al. (2015) [33], which focused only on BMC, was analyzed separately with a narrative report.

\section{Hip bone mineral density and lean mass}

The 8 analyzed studies [22, 25-27, 30, 32, 37, 39] comprised a total of 2022 patients. Their quality varied by 5 points in the NOS score [25] under the maximum score of 9 points [39] (Table 4). Three studies reported an analysis of children's health $[25,27,32]$, and 5 studies were about postmenopausal or older subjects [22, 30, 37, 39, 40]. The association between the evolution of hip BMD and the evolution of lean mass was significantly correlated in all studies except for that of Chen et al. (1997) [40] ( $p$-value >0.05) and Hrafnkelsson et al. (2015) [32] ( $p$-value> 0.05). The correlation coefficients $r$ varied from 0.05 [40] to 0.69 [27] (Fig. 2). Among these results, the correlation coefficients $r$ 


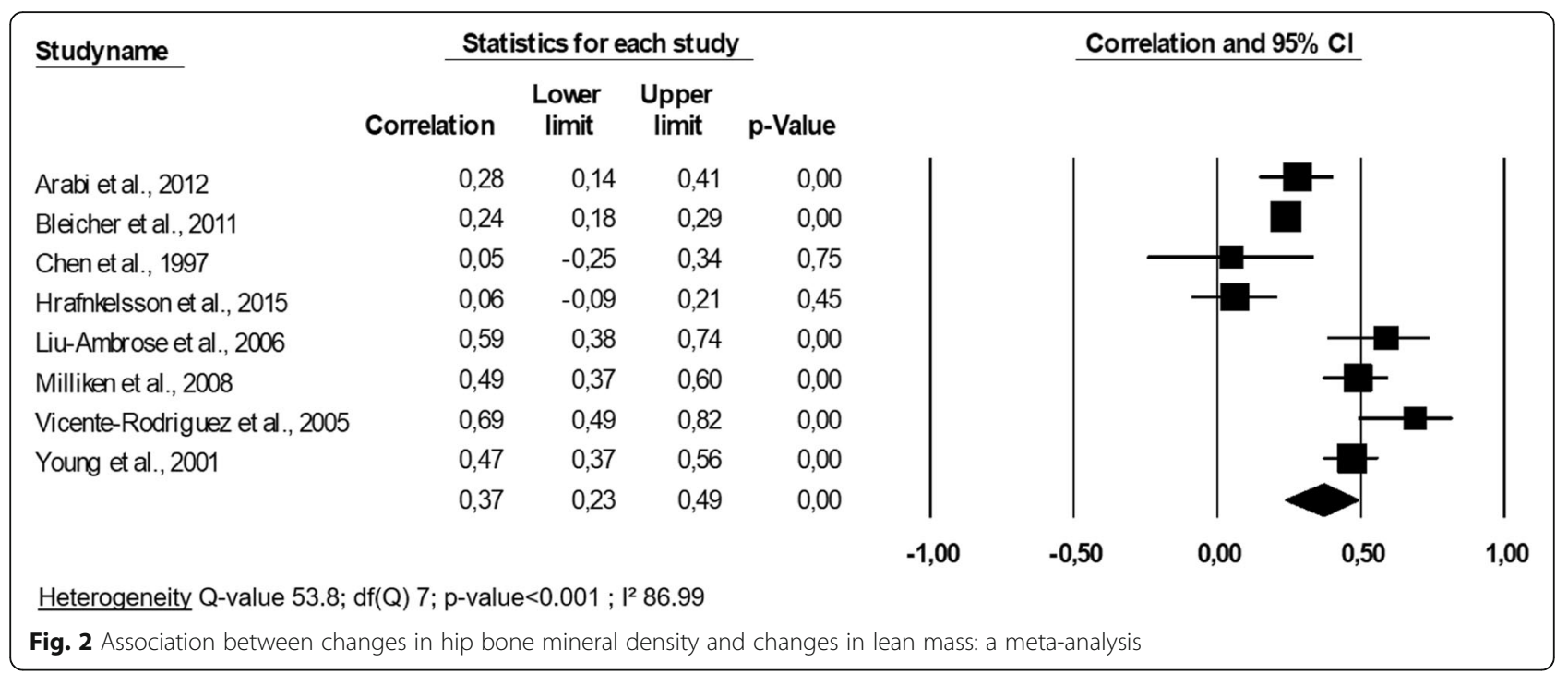

were imputed from the available $\beta$ coefficient for all of the studies except for that of Liu-Ambrose et al. (2006) [22] and that of Vicente-Rodriguez et al. (2005) [27]. A metaanalysis was performed to combine the results of these different studies (Fig. 2).

An overall correlation coefficient $\mathrm{r}$ of 0.37 (95\% CI $0.23-$ $0.49, p$-value $<0.001$ ) was yielded by pooling the results of the 8 studies, indicating that the prospective changes in hip BMD were significantly and moderately correlated to the changes in lean mass. The subgroup analysis indicated that there was a significant difference in effect size ( $p$-value< 0.001 ) between that of children ( 3 studies, $r=0.43$ (95\% CI: 0.06-0.69)) and that of adults and older individuals (5 studies, $r=0.34$ (95\% CI $0.19-0.48)$ ). There was heterogeneity in our meta-analysis $\left(\mathrm{I}^{2}=86.99, p\right.$-value $\left.<0.001\right)$, so a metaregression was performed to explore this phenomenon. We found no significant impact at the level of the quality of study, the mean age analyzed, the sex or the duration of the follow-up on the overall effect size (all $p$-values $>0.05$ ). The
Eggers' regression analysis demonstrated that publication bias was not present ( $p$-value $=0.27$ ). The one-way sensitivity analysis showed the consistency of our results, showing that they had roughly the same correlation coefficient, and the heterogeneity $\mathrm{I}^{2}$ value exceeded $85.75 \%$ in all cases.

\section{Femoral neck bone mineral density and lean mass}

Four studies of a total of 649 individuals investigated the relationship between femoral neck change and lean mass change $[25,30,37,40]$, and the methodological quality ranged from satisfactory [25] to good [30, 37, 40]. The studies focused on adulthood (i.e., in this case, premenopausal women) except one that focused on childhood [25]. Only one study, that of Chen et al. (1997) [40], found no significant association between the evolution of femoral neck $\mathrm{BMD}$ and the evolution of lean mass. The set of correlation coefficients is available in Fig. 3, demonstrating a pooled correlation coefficient $\mathrm{r}$ of 0.33 (95\% CI $0.16-0.49$ ), a value that is moderate but significant.

\begin{tabular}{|c|c|c|c|c|c|c|c|c|c|}
\hline \multirow[t]{2}{*}{ Study name } & \multicolumn{4}{|c|}{ Statistics for each study } & & \multicolumn{4}{|c|}{ Correlation and $95 \% \mathrm{Cl}$} \\
\hline & Correlation & $\begin{array}{l}\text { Lower } \\
\text { limit }\end{array}$ & $\begin{array}{c}\text { Upper } \\
\text { limit }\end{array}$ & Z-Value & p-Value & & & & \\
\hline Arabi et al., 2012 & 0,30 & 0,17 & 0,42 & 4,26 & 0,00 & & & & \\
\hline Chen et al., 1997 & 0,06 & $-0,24$ & 0,35 & 0,39 & 0,70 & & & & \\
\hline Milliken et al., 2009 & 0,32 & 0,18 & 0,45 & 4,25 & 0,00 & & & & \\
\hline \multirow[t]{3}{*}{ Young et al., 2011} & 0,52 & 0,42 & 0,61 & 8,97 & 0,00 & & & & \\
\hline & 0,33 & 0,16 & 0,49 & 3,74 & 0,00 & & & & \\
\hline & & & & & & $-1,00$ & $-0,50$ & 0,00 & 1,00 \\
\hline Heterogeneity Q-valu & ue $14.8 ; \operatorname{df}(Q)$ & ; p-value $=$ & $=0.002 ; I^{2}$ & $\left.\right|^{2} 79.06$ & & & & & \\
\hline
\end{tabular}


A subgroup analysis was not feasible since there was only one study in the 'children' group. Heterogeneity was found in this analysis $\left(\mathrm{I}^{2}=79.06, p\right.$-value $\left.=0.002\right)$. When we inserted moderators into the meta-regression, we observed that the quality level of the study, the mean age, the sex and the duration of follow-up did not have a significant impact on the pooled effect size (all $p$ values $>0.05)$. The Eggers' regression test showed there was no publication bias ( $p$-value $=0.24$ ). A one-way analysis allowed us to determine that the study of Young et al. (2011) [25] had a significant influence on the metaanalysis model. Indeed, when this study was removed from the pooling, the heterogeneity was much lower and not significant $\left(\mathrm{I}^{2}=22.36, p\right.$-value $\left.=0.28\right)$. In this case, the pooled correlation coefficient raised up to 0.42 , showing that, through the sensitivity analysis, the study of Young et al. was source of heterogeneity, probably due to its focus on another population (ie., young female twins).

\section{Lumbar spine bone mineral density and lean mass}

The four studies examining the prospective link between the evolution of lumbar spine BMD and the evolution of the lean mass were the same as the four studies described in the paragraph above, and they therefore have the same characteristics [25, 30, 37, 40]. One study showed no significant association between the two entities tested [40]. The overall correlation coefficient $r$ was 0.32 (95\% CI 0.19-0.43), modest to substantial heterogeneity between studies was observed $\left(\mathrm{I}^{2}=60.91, p\right.$-value $\left.=0.05\right)($ Fig. 4$)$, and the one-way sensitivity analysis confirming this finding by demonstrating that the value of $\mathrm{I}^{2}$ remained in the same range. When considering the quality level of the study, neither the mean age nor the duration of follow-up as moderators within a meta-regression, neither of those nor significantly stood out as moderators within the metaregression (all $p$-values $>0.05$ ). After applying Egger's regression analysis, no publication bias was established $(p$-value $=0.33)$.

\section{Total body bone mineral density and lean mass}

The three studies included a total of 246 patients in this meta-analysis. Two studies were focused on childhood $[32,35]$, and one in older subjects [40], and all were of good quality (NOS score $=8$ points for all). One unique study by Chen et al. (1997) [40] showed no significant association between the changes in the two entities tested. When we pooled results of all studies, a correlation coefficient $\mathrm{r}$ of 0.53 was yielded (95\% CI -0.230.89 ) and was not significant ( $p$-value $=0.16$ ) (Fig. 5). A large heterogeneity was found ( $p$-value $<0.001)$. After performing the one-way analysis (i.e., one-to-one model withdrawal), heterogeneity remained high and significant. Specifically, the study by Cadogan et al. reported a much higher $r$ value than any of the other included studies. No specific difference with others studies was noted regarding general characteristics.

A meta-regression could not be applied since too few studies were included. Finally, we did not find the presence of a publication bias, given that the $p$-value of Egger's regression equaled 0.57 .

\section{Bone mineral content and lean mass}

The study of Heidemann et al. (2015) [33] was not focused on the changes of BMD but rather in the changes of BMC. Therefore, this study required a separate analysis. The research was focused on children over a two-year follow-up period and appeared to be of satisfactory quality (6 points out of 9). Heidemann et al. (2015) pointed out in their regression model that bone content accretion was significantly predicted by changes in lean mass $(p$-value $<0.001)$.

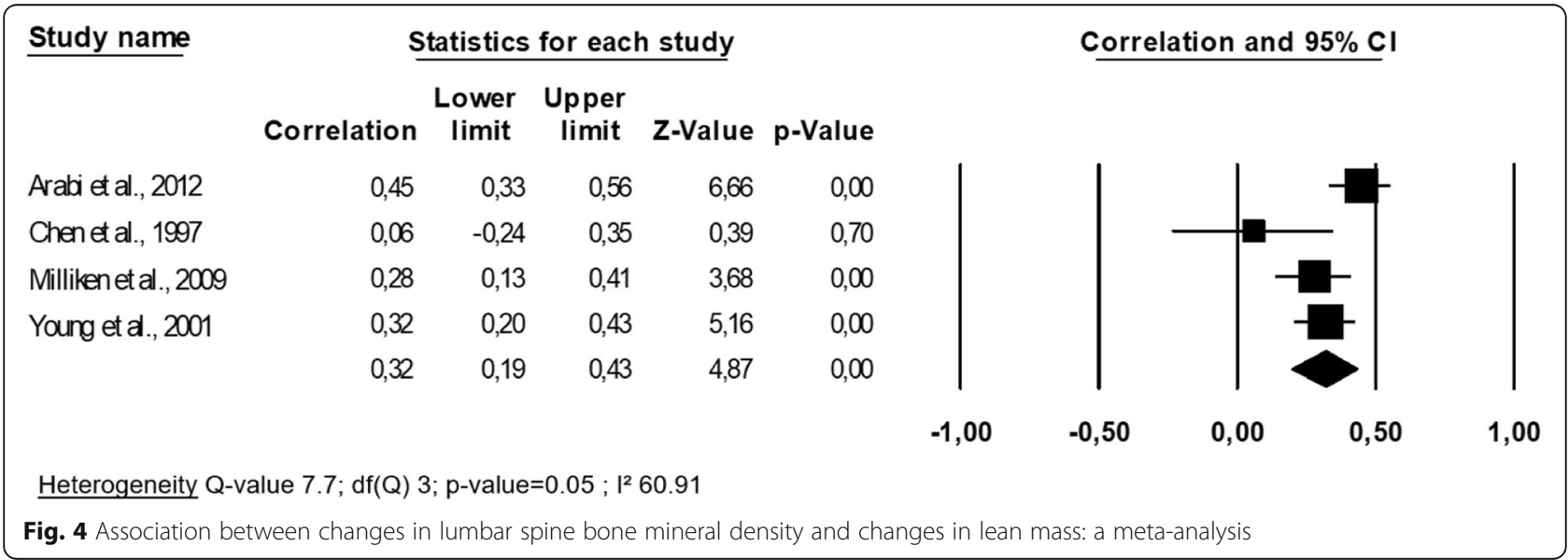




\begin{tabular}{|c|c|c|c|c|c|c|c|c|c|}
\hline \multirow[t]{2}{*}{ Studyname } & \multirow[b]{2}{*}{ Correlation } & \multicolumn{3}{|c|}{ Statistics for each study } & \multirow[b]{2}{*}{$\mathrm{p}$-Value } & & \multicolumn{2}{|c|}{ Correlation and $95 \% \mathrm{Cl}$} & \\
\hline & & $\begin{array}{c}\text { Lower } \\
\text { limit }\end{array}$ & $\begin{array}{c}\text { Upper } \\
\text { limit }\end{array}$ & Z-Value & & & & & \\
\hline Hrafnkelsson et al., 2015 & 0,17 & 0,02 & 0,32 & 2,18 & 0,03 & & & & \\
\hline Cadogan et al., 1998 & 0,92 & 0,85 & 0,96 & 9,27 & 0,00 & & & & \\
\hline \multirow[t]{3}{*}{ Chen et al., 1997} & 0,05 & $-0,25$ & 0,34 & 0,32 & 0,75 & & & & \\
\hline & 0,53 & $-0,23$ & 0,89 & 1,41 & 0,16 & & & & \\
\hline & & & & & & $-1,00$ & $-0,50$ & 0,00 & 1,00 \\
\hline \multicolumn{10}{|c|}{ Heterogeneity Q-value 61.1; df(Q) 2; p-value $<0.001 ;\left.\right|^{2} 96.72$} \\
\hline
\end{tabular}

\section{Relationship between changes in bone mass and changes in muscle strength}

Three studies examined the link between the evolution of the BMD and that of muscle strength, in peri- or postmenopausal women $[28,29,38]$. However, since these three studies were performed by the same author, we did not perform a meta-analysis because that the samples likely overlap. In addition, two of these three studies appeared to focus on the same cohort of subjects. All three studies conclude that there is a statistically significant association between decreased muscle strength in postmenopausal women and bone loss ( $p$-values $<0.05$ ). For these studies, no correlation coefficient was calculated, and the authors demonstrated an association simply based on differences in bone loss rate between those with increased grip strength and those with having decreased grip strength. These three studies are of fairly good quality (7 out of 9 points).

Then, the study of Wang et al. (2007) [26], which was conducted on children two years of age, also showed that the change of BMC (but not the BMD) was significantly correlated with the change of volumetric contraction strength in the limbs $(\mathrm{r} \geq 0.22, p$-value $<0.05)$. This study was of satisfactory quality (6 out of 9 points).

\section{Relationship between changes in bone mass and changes in physical performance}

Finally, the study by Kwon et al. (2007) [31], investigated the link between BMD changes and changes in physical performance, as measured by the $5-\mathrm{m}$ usual walking speed; this study was on older women and was methodologically excellent ( 9 points). This study concluded that a decline in BMD was significantly related to a decline in usual walking speed (correlation coefficient $\mathrm{r}=0.21, p$-value $=0.004)$.

\section{Discussion}

In this work we have synthesized data from the literature concerning the link between the evolution of skeletal status (specifically, BMD) and of various muscle components.
Fifteen studies were included in our analysis, 10 of which were related to lean mass, 4 to muscle strength, and 1 to physical performance.

\section{Association between changes in bone mineral density and changes in lean mass}

Using a meta-analysis approach, our results showed a significant association between the evolution of the bone mass and that of the mass muscle. The overall correlation coefficient $r$ was significant and equal to 0.37 when considering bone hip density, 0.33 for femoral neck BMD and 0.32 for the lumbar spine. One notable exception, however, was that the link was not significant when measuring the bone density of the whole body ( $p$-value $=0.16$ ). However, this BMD measurement site does not appear optimal and would tend to overestimate the BMD and thereby underestimate osteopenia [41]. If one omits the unreliable results concerning the total body BMD, the magnitude of the correlation at the different sites seems to be the same ( $r$ varies from 0.32 to 0.37 ); this outcome suggests the same general trend of parallel evolution in the two entities of bone and muscle regardless of the measurement site.

A clear significant link was found ( $p$-value $<0.001)$ between the two bone and lean mass, but it was moderate and thus one only partially explained the evolution of the other. Other factors should therefore be taken into account when considering the evolution of the masses of the bone-muscle unit (e.g., genetics; the genes that have been identified for their implications in sarcopenia [42] appear to be different from those involved in osteoporosis [43]). Evaluating the bone mass by using BMD or BMC measurements did not appear to influence the conclusions about the association between the two parameters.

The quite obvious relationship in development during the evolution of the bone mass and the lean mass could be explained mainly by mechanics: the muscle mass, which develops following a physical activity or an adapted dietary intake, will exert a net tension at the level of muscle insertion on the bone, resulting in a bone 
accruement $[31,44]$. During the maturing phase and the aging process, the opposite was observed: the physiological changes are linked to decreased physical activity, and a change in nutritional status leads to a decline in lean mass, thus no longer exerting its mechanistic effect on the bones of the body and causing a simultaneous decline in bone mass. Our study shows that this link is more marked during childhood and therefore during the developmental process $(r=0.43)$ than during the aging process $(r=0.34)$. We hypothesize that this significant difference in effect $(p<0.001)$ may be related to multiple other influencing factors (such as diet, gene expression, peak bone and lean mass acquired during childhood, ...) that have had the time to impact musculoskeletal health during adulthood and aging. Indeed, only a partial proportion of the association in changes was explained by the relationship between bone and muscle (i.e., less of $15 \%$ of the variance accounted for): other clinical implications have to be considered.

\section{Association between changes in bone mineral density and changes in muscle strength}

Few studies have been identified regarding this aspect: 3 studies by the same author, and one in children. In both situations, we found significant associations. Although no meta-analysis could be done, these studies revealed a link between the evolution of muscle strength and that of the BMD. A biological plausibility can hypothetically explain this observed association: that of mechanical strain of the muscle on bone tissue metabolism $[12,45]$.

\section{Association between changes bone mineral density and changes in muscle performance}

We have only one study regarding the relationship of the evolution of the BMD compared to that of physical performance, although this issue deserves further investigation. There are many studies on whether physical performance (weak or good) is a determinant of low or good bone mass [46] but not on if there is a parallel evolution between the two entities, although this is a more preventive idea. However, in the only study that highlighted the link between bone mass and physical performance, the correlation was significant albeit moderate $(r=0.21)$. This significant association could be explained by the direct link between the physical function (and by this, the performance) and the muscle action on the bone, as emphasized previously by several authors [31, 44].

\section{Strengths and limitations}

This study is the first to employ a meta-analysis to synthetize the results from studies examining an association between the parallel evolution of bone and muscle status. One asset of our study is that we looked in multiple databases, although some databases could not be consulted following logistical barriers. All processes have been rigorous, using the PRISMA statements to ensure a good level of reporting of our research. In addition, our meta-analysis has highlighted a gap in the scientific literature on our theme: few studies exist in older men and few studies focus on certain muscle components (i.e., changes in muscle strength and changes in physical performance). These areas deserve to be more studied. Our present analysis, however, has certain limitations, so it is necessary to consider its interpretation in the context of these limitations. First, even though we made every effort to contact the authors to obtain the missing data that was essential for the quantitative synthesis of the results, the majority of the authors did not answer our calls. Therefore, we had to resort to a technical imputation of the correlation coefficient $r$ from the coefficient $\beta$. This technique is mathematically developed and has proved its merits in order to pool the results of a metaanalysis. Indeed, it seems preferable to impute the data rather than to omit the studies interested in the topic, which could have led to a bias. However, the limitations of the method are important. First, the correlation coefficient obtained is not real data, so we must interpret them with caution. Also, the fact of using in the metaanalysis the correlation coefficients does not allow, by definition, to consider in the statistical relationship the potential confounding factors.

We also identified the potential sources of clinical and statistical heterogeneity among the included references: the sex of the subjects studied, the quality of the studies, and the diverse duration of follow-up and age-group of interest (i.e., differences in protocols). However, we have taken these parameters into account by using a randomeffect model and performing subgroup or meta-regression analyses, showing no effect of duration of follow-up but significant differences in outcomes between children and adults (i.e., the association is significantly greater in children than in adults). Inclusion of studies with short follow-up may lead to bias as the minimum duration to observe change in bone and muscle in a non-diseased population is at minimum 2 years [47]. We hypothesize that this heterogeneity could also be induced by the small number of studies that were included in each of the metaanalyses, and other good quality studies should be conducted to reinforce our analysis, despite the fact that this statement seems clear (i.e., although there is indeed a significant association, it seems moderate). It should also be noted that there remains a possibility that our analysis has necessarily excluded unpublished studies concerning our theme, representing a threat to its validity. However, the publication bias was evaluated and did not show any bias at this level even if some relevant papers could always be missed. Finally, it should also be recognized that the instrument that was used to measure the methodological 
quality of the studies also had its limitations, particularly in terms of its interpretation. This could influence our descriptive but also statistical analysis (i.e., the results of the meta-regression). Next, we have studied in this metaanalysis the magnitude of bone-muscle associations, by pooling the correlation coefficient $r$ of all studies, regardless of sex and life-stage. It is legitimate to group together these coefficients, since we seek here to describe the intensity of the relationship. However, subgroup analyzes were performed as well as meta-regressions considering its covariates. We have therefore concluded that the intensity of the "bone-muscle" association is even higher during childhood, but no effect has been established with regard to sex. There are however sub-groups for which we do not have sufficient data, which represent a limit of our meta-analysis. Finally, DXA bone site and site of muscle measure might be different, resulting in overall lower correlation. For the studies that used DXA to measure muscle, we noted that lean mass is not equivalent to muscle mass: some care should be made in interpreting these results.

\section{Conclusion}

Our analysis highlighted a structural relationship between the changes, both during childhood and during the aging process, of bone mass and of markers of muscle function. There appear to be one or more factors linking decline in bone and muscle and hence interventions may well impact the concurrent decline in muscle and bone. Further research would be necessary to elucidate whether interventions targeting bone and/or muscle would be effective in altering this concurrent decline.

\section{Acknowledgements}

We warmly thank Dr. Macdonald and Dr. Liu-Ambrose for providing us with important information regarding their articles, allowing us to conduct our meta-analysis in the best and most accurate way possible. Additionally, there is no funding to declare.

\section{Authors' contributions}

Study design: ML, CB, OB, and ND. Study conduct: ML, and CB. Data collection: ML, and CB. Data analysis: ML. Data interpretation: ML, CB, JYR, OB. Drafting manuscript: ML. Revising manuscript content: $M L, C B, N D$, JYR, and $\mathrm{OB}$. Approving final version of manuscript: $M L, C B, N D$, JYR, and $O B$. ML takes responsibility for the integrity of the data analysis.

\section{Funding}

None.

\section{Availability of data and materials}

The datasets used and/or analysed during the current study are available from the corresponding author on reasonable request.

\section{Ethics approval and consent to participate}

Not applicable.

\section{Consent for publication}

Not applicable.

\section{Competing interests}

The authors declare that they have no competing interests.

\section{Author details}

'World Health Organization Collaborating Center for Public Health Aspects of Musculoskeletal Health and Aging, Department of Public Health,

Epidemiology and Health Economics, University of Liège, CHU B.23 - Quartier Hôpital, Avenue Hippocrate, 13, 4000 Liège, Belgium. ${ }^{2}$ ULiège Library, University of Liège, Liège, Belgium. ${ }^{3}$ Biochemistry Department, College of Science, King Saud University, Riyadh, Kingdom of Saudi Arabia. ${ }^{4}$ Department of Sports and Rehabilitation Sciences, University of Liège, Liège, Belgium.

Received: 18 March 2019 Accepted: 4 August 2019

Published online: 14 September 2019

\section{References}

1. Kamper SJ, Henschke N, Hestbaek L, Dunn KM, Williams CM. Musculoskeletal pain in children and adolescents. Brazilian J Phys Ther. 2016;20:275-84. https://doi.org/10.1590/bjpt-rbf.2014.0149.

2. Sudhagoni RG, Wey HE, Djira GD, Specker BL. Longitudinal effects of fat and lean mass on bone accrual in infants. Bone. 2012;50:638-42. https://doi. org/10.1016/.jbone.2011.11.011.

3. Roux CH, Guillemin F, Boini S, Longuetaud F, Arnault N, Hercberg S, et al. Impact of musculoskeletal disorders on quality of life: an inception cohort study. Ann Rheum Dis. 2005;64:606-11. https://doi.org/10.1136/ard.2004.020784.

4. Taaffe DR, Marcus R. Musculoskeletal health and the older adult. J Rehabil Res Dev. 37:245-54 http://www.ncbi.nlm.nih.gov/pubmed/10850831. Accessed 18 Aug 2018.

5. Beaudart $C$, Zaaria M, Pasleau F, Reginster J-Y, Bruyère O. Health outcomes of sarcopenia: a systematic review and meta-analysis. PLoS One. 2017;12: e0169548. https://doi.org/10.1371/journal.pone.0169548.

6. Locquet M, Beaudart C, Hajaoui M, Petermans J, Reginster J-Y, Bruyère O. Three-year adverse health consequences of sarcopenia in communitydwelling older adults according to 5 diagnosis definitions. J Am Med Dir Assoc. 2018. https://doi.org/10.1016/j.jamda.2018.06.004.

7. Cooper C. The crippling consequences of fractures and their impact on quality of life. Am J Med. 1997;103:S12-9. https://doi.org/10.1016/ S0002-9343(97)90022-X.

8. Reginster J-Y, Burlet N. Osteoporosis: a still increasing prevalence. Bone. 2006:38:4-9. https://doi.org/10.1016/j.bone.2005.11.024

9. Beaudart C, Locquet $M$, Reginster $J-Y$, Delandsheere L, Petermans J, Bruyère O. Quality of life in sarcopenia measured with the SarQo ${ }^{\bullet}$ : impact of the use of different diagnosis definitions. Aging Clin Exp Res. 2017;30:307-13.

10. Blasimme A. Physical frailty, sarcopenia, and the enablement of autonomy: philosophical issues in geriatric medicine. Aging Clin Exp Res. 2017;29:5963. https://doi.org/10.1007/s40520-016-0714-3.

11. Frost HM. Bone's mechanostat: a 2003 update. Anat Rec. 2003;275A:1081101. https://doi.org/10.1002/ar.a.10119.

12. Schoenau E. From mechanostat theory to development of the \&quot; Functional Muscle-Bone-Unit\&quot. J Musculoskelet Neuronal Interact. 5:232-8 http://www.ncbi.nlm.nih.gov/pubmed/16172514. Accessed 13 Sept 2018.

13. Schoenau E, Fricke O. Mechanical influences on bone development in children. Eur J Endocrinol. 2008;159 suppl_1:S27-31. https://doi.org/10.1530/EJE-08-0312.

14. Ho-Pham LT, Nguyen UDT, Nguyen TV. Association between lean mass, fat mass, and bone mineral density: a meta-analysis. J Clin Endocrinol Metab. 2014;99:30-8. https://doi.org/10.1210/jc.2013-3190.

15. Marin RV, Pedrosa MAC, Moreira-Pfrimer LDF, Matsudo SMM, Lazaretti-Castro M. Association between lean mass and handgrip strength with bone mineral density in physically active postmenopausal women. J Clin Densitom. 2010;13:96-101. https://doi.org/10.1016/j.jocd.2009.12.001.

16. Kritz-Silverstein D, Barrett-Connor E. Grip strength and bone mineral density in older women. J Bone Miner Res. 2009;9:45-51. https://doi. org/10.1002/jbmr.5650090107.

17. Ozgocmen S, Karaoglan B, Cimen OB, Yorgancioglu ZR. Relation between grip strength and hand bone mineral density in healthy women aged 3070. Singap Med J. 2000;41:268-70 http://www.ncbi.nlm.nih.gov/ pubmed/11109342. Accessed 18 Aug 2018.

18. Lindsey C, Brownbill RA, Bohannon RA, llich JZ. Association of Physical Performance Measures with Bone Mineral Density in postmenopausal women. Arch Phys Med Rehabil. 2005;86:1102-7. https://doi.org/10.1016/j.apmr.2004.09.028.

19. Khazzani H, Allali F, Bennani L, Ichchou L, El Mansouri L, Abourazzak $F E$, et al. The relationship between physical performance measures, bone mineral density, falls, and the risk of peripheral fracture: a cross- 
sectional analysis. BMC Public Health. 2009;9:297. https://doi.org/10.11 86/1471-2458-9-297.

20. El Khoury C, Pinti A, Lespessailles E, Maalouf G, Watelain E, El Khoury G, et al. Physical performance variables and bone mineral density in a Group of Young Overweight and Obese men. J Clin Densitom. 2018;21:41-7. https:// doi.org/10.1016/j.jocd.2016.07.004.

21. Moher D, Liberati A, Tetzlaff J, Altman DG, PRISMA Group. Preferred Reporting Items for Systematic Reviews and Meta-Analyses: The PRISMA Statement. PLoS Med. 2009;6:e1000097. https://doi.org/10.1371/journal. pmed.1000097.

22. Liu-Ambrose T, Kravetsky L, Bailey D, Sherar L, Mundt C, Baxter-Jones A, et al. Change in lean body mass is a major determinant of change in areal bone mineral density of the proximal femur: a 12-year observational study. Calcif Tissue Int. 2006;79:145-51.

23. Peterson RA, Brown SP. On the use of Beta coefficients in meta-analysis. J Appl Psychol. 2005;90:175-81. https://doi.org/10.1037/0021-9010.90.1.175.

24. Higgins JPT, Thompson SG, Deeks JJ, Altman DG. Measuring inconsistency in meta-analyses. BMJ. 2003;327:557-60. https://doi.org/1 0.1136/bmj.327.7414.557.

25. Young D, Hopper JL, Macinnis RJ, Nowson CA, Hoang NH, Wark JD. Changes in body composition as determinants of longitudinal changes in bone mineral measures in 8 to 26 -year-old female twins. Osteoporos Int. 2001;12:506-15.

26. Wang $Q$, Alén $M$, Nicholson $P$, Suominen $H$, Koistinen $A$, Kröger $H$, et al. Weight-bearing, muscle loading and bone mineral accrual in pubertal girls-a 2-year longitudinal study. Bone. 2007;40:1196-202. https://doi.org/1 0.1016/j.bone.2006.12.054.

27. Vicente-Rodriguez G, Ara I, Perez-Gomez J, Dorado C, Calbet JAL. Muscular development and physical activity as major determinants of femoral bone mass acquisition during growth. Br J Sports Med. 2005;39:611-6.

28. Sirola J, Rikkonen $\mathrm{T}$, Tuppurainen $\mathrm{M}$, Honkanen R, Jurvelin JS, Kröger $\mathrm{H}$. Maintenance of muscle strength may counteract weight-loss-related postmenopausal bone loss - a population-based approach. Osteoporos Int. 2006:17:775-82

29. Sirola J, Rikkonen T, Tuppurainen M, Jurvelin JS, Kröger H. Association of grip strength change with menopausal bone loss and related fractures: a population-based follow-up study. Calcif Tissue Int. 2006;78:218-26.

30. Milliken LA, Cussler E, Zeller RA, Choi JE, Metcalfe L, Going SB, et al. Changes in soft tissue composition are the primary predictors of 4-year bone mineral density changes in postmenopausal women. Osteoporos Int. 2009;20:347-54

31. Kwon J, Suzuki T, Yoshida H, Kim H, Yoshida Y, Iwasa H, et al. Association between change in bone mineral density and decline in usual walking speed in elderly community-dwelling Japanese women during 2 years of follow-up. J Am Geriatr Soc. 2007;55:240-4.

32. Hrafnkelsson H, Sigurdsson G, Magnusson KT, Sigurdsson EL, Johannsson E. Fat mass increase in 7-year-old children: more bone area but lower bone mineral density. J Bone Miner Metab. 2013;31:442-8.

33. Heidemann M, Holst R, Schou AJ, Klakk H, Husby S, Wedderkopp N, et al. The influence of anthropometry and body composition on Children's bone health: the childhood health, activity and motor performance school (the CHAMPS) study. Denmark Calcif Tissue Int. 2014;96:97-104.

34. Chen Z, Lohman TG, Stini WA, Ritenbaugh C, Aickin M. Fat or lean tissue mass: which one is the major determinant of bone mineral mass in healthy postmenopausal women? J Bone Min Res. 1997;12:144-51. https://doi.org/1 0.1359/jbmr.1997.12.1.144.

35. Cadogan J, Blumsohn A, Barker ME, Eastell R. A longitudinal study of bone gain in pubertal girls: anthropometric and biochemical correlates. J Bone Miner Res. 1998;13:1602-12.

36. Bleicher K, Cumming RG, Naganathan V, Travison TG, Sambrook PN, Blyth FM, et al. The role of fat and lean mass in bone loss in older men: findings from the CHAMP study. Bone. 2011;49:1299-305. https://doi.org/10.1016/j. bone.2011.08.026.

37. Arabi A, Baddoura R, El-Rassi R, El-Hajj FG. PTH level but not $25(\mathrm{OH})$ vitamin D level predicts bone loss rates in the elderly. Osteoporos Int. 2012;23:971-80.

38. Sirola J, Tuppurainen M, Honkanen R, Jurvelin JS, Kröger H. Associations between grip strength change and axial postmenopausal bone loss - a 10year population-based follow-up study. Osteoporos Int. 2005;16:1841-8. https://doi.org/10.1007/s00198-005-1944-y.

39. Yanf S, Center JR, Eisman JA, Nguyen TV. Association between fat mass, lean mass, and bone loss: the Dubbo Osteoporosis Epidemiology Study.
Osteoporos Int. 2015;26(4):1381-6. https://www.ncbi.nlm.nih.gov/ pubmed/25572048.

40. Ho-Pham LT, Nguyen UDT, Nguyen TV. Association between lean mass, fat mass, and bone mineral density: a meta-analysis. J Clin Endocrinol Metabol. 2014;99:30-8. https://academic.oup.com/jcem/article/99/1/30/2836155.

41. Rajaei A, Dehghan P, Ariannia S, Ahmadzadeh A, Shakiba M, Sheibani K. Correlating whole-body bone mineral densitometry measurements to those from local anatomical sites. Iran J Radiol. 2016;13:e25609. https://doi.org/10.5 812/iranjiadiol.25609.

42. Kashyap L, Perera S, Fisher AL. Identification of novel genes involved in sarcopenia through RNAi screening in Caenorhabditis elegans. J Gerontol A Biol Sci Med Sci. 2012;67:56-65. https://doi.org/10.1093/gerona/glr072.

43. Marini F, Brandi ML. Genetic determinants of osteoporosis: common bases to cardiovascular diseases? Int J Hypertens. 2010;2010. https://doi.org/10.4 061/2010/394579

44. Cianferotti L, Brandi ML. Muscle-bone interactions: basic and clinical aspects. Endocrine. 2014;45:165-77. https://doi.org/10.1007/s12020-013-0026-8.

45. Avin KG, Bloomfield SA, Gross S, Warden SJ. Biomechanical aspects of the muscle-bone interaction. Curr Osteoporos Rep. 2015;13(1):1-8. https://www. ncbi.nlm.nih.gov/pmc/articles/PMC4306629/.

46. Shin H, Panton LB, Dutton GR, llich JZ. Relationship of physical performance with body composition and bone mineral density in individuals over 60 years of age: a systematic review. SAGE-Hindawi Access to Res J Aging Res. 2011;14. https://doi.org/10.4061/2011/191896.

47. Curtis E, Litwic A, Cooper C, Dennison E. Determinants of muscle and bone aging. J Cell Physiol. 2015;230:2618-25. https://doi.org/10.1002/jcp.25001.

\section{Publisher's Note}

Springer Nature remains neutral with regard to jurisdictional claims in published maps and institutional affiliations.

Ready to submit your research? Choose BMC and benefit from:

- fast, convenient online submission

- thorough peer review by experienced researchers in your field

- rapid publication on acceptance

- support for research data, including large and complex data types

- gold Open Access which fosters wider collaboration and increased citations

- maximum visibility for your research: over $100 \mathrm{M}$ website views per year

At $\mathrm{BMC}$, research is always in progress.

Learn more biomedcentral.com/submissions 